\title{
Tapirs from the Pleistocene of Venezuela
}

\author{
Elizete C. Holanda and Ascanio D. Rincón
}

Acta Palaeontologica Polonica 57 (3), 2012: 463-472 doi: http://dx.doi.org/10.4202/app.2011.0001

The living tapir Tapirus terrestris is widely distributed in Venezuela, occurring mainly south of the Orinoco, while being absent from arid, high Andean and insular areas. Here, we describe new material of fossil tapirs from two Pleistocene localities of Venezuela: Zumbador Cave and El Breal de Orocual. Based on its size and morphology, the material from Zumbador Cave (skull, mandible and postcrania) is assigned to the extant $T$. terrestris, and represents the most northwestern fossil record of this species in South America. By contrast, the remains from the tar seep of El Breal de Orocual are more gracile, and differ from T. terrestris and other fossil and living species from South America in the presence of a metastylid on the lower cheek teeth. We tentatively assign the latter remains to Tapirus sp., based on juvenile and isolated dentary material. However, the possibility that these specimens may represent a new species or an immigrant from North America cannot be completely excluded.

Key words: Mammalia, Perissodactyla, Tapirus, Pleistocene, El Breal de Orocual, Zumbador Cave, Venezuela.

Elizete C. Holanda [elizete.holanda@gmail.com], Programa de Pós-Graduação em Geociências, Universidade Federal do Rio Grande do Sul. Porto Alegre, RS, Brasil and Setor de Paleontologia, Museu de Ciências Naturais, Fundação Zoobotânica do Rio Grande do Sul, Av. Dr. Salvador França, 1427, Jd. Botânico, CEP 90690-000, Porto Alegre, Rio Grande do Sul, Brazil; Ascanio D. Rincón [ascaniodaniel@gmail.com], Instituto Venezolano de Investigaciones Científicas, Lab. Biología de Organismos Centro de Ecología, Km 11 de la Carretera Panamericana, Apartado Postal 20632, Caracas 1020A, Venezuela.

This is an open-access article distributed under the terms of the Creative Commons Attribution License (for details please see creativecommons.org), which permits unrestricted use, distribution, and reproduction in any medium, provided the original author and source are credited. 
FoF Full text $(548.9 \mathrm{kB})$ 